\title{
A helyi közösségi közlekedés finanszírozásának környezete
}

\section{The Operating and Financing Environmental of Local Public Transport}

\author{
Sz. TóTH \\ Debreceni Egyetem, Gazdaságtudományi Kar, toth.szabolcs@dkv.hu
}

\begin{abstract}
Absztrakt. Hazánkban a helyi közösségi közlekedés finanszírozásának megoldása egyre nagyobb terhet jelent a közszolgáltatás ellátásáért felelősöknek. Az ágazat hazai intézményrendszere az európai standardoknak megfelel, azonban a bevételeket elemezve megállapítható, hogy a probléma gyökere alapvetően a magyarországi támogatási struktúrában keresendő. Az ingyenes és a kedvezményes utazások után járó szociálpolitikai menetdíj-támogatási rendszer felülvizsgálata és az árkiegészítés mértékének reális kiigazítása ma már elengedhetetlen, az állami normatív támogatás mértéke nem képes kompenzálni az ebből eredő bevétel kiesést a helyi közösségi közlekedésben. Az önkormányzatoknak a közszolgáltatás ellátásához kapcsolódó finanszírozási terhe évröl-évre egyre nagyobb. A folyamatos müködés biztosítása mellett elengedhetetlen a szolgáltatás minöségének fenntartása és a magasabb utasszám érdekében az ágazat folyamatos fejlesztése.
\end{abstract}

Abstract. In Hungary the financing of the local public transportation is becoming a great obligation for the public service providers. The institutional framework of the national segment is in line with the european standards, nevertheless based on the analysis of the revenues it is clear to see that the core problem is to be found in the hungarian compensation system. The free and reduced rate fares originating from the social fare subvention system need to be reviewed and the realistic adjustment of the price compensation is evitable, due to the fact that the volume of the state normative compensation is not able to reach the volume off loss in revenues in the local public transportation. The amount of compensation required by local governments is raising every year. Besides assuring the stable operation it is also important to maintain the high quality of services and improve the segment in order to raise the number of passangers.

\section{Bevezetés}

Az urbanizációs folyamatoknak köszönhetően a városban élő lakosság lélekszáma a következő években ugrásszerűen meg fog növekedni. Már napjainkban is tapasztalhatjuk azt, hogy utazási céljaink elérése egyre több időt vesz igénybe a közlekedési dugók kialakulása miatt. A városi közösségi közlekedés szerepe a városban élő lakosság arányának növekedésével ezen okokból várhatóan egyre jobban fel fog értékelődni. Napjainkban a közlekedési módok városon belüli részarányát elemezve kijelenthető, hogy a lakosság közintézményekbe, munkahelyre történő eljutásában a különböző módokat tekintve jelentős eltérések tapasztalhatók. $\mathrm{Az}$ erősen motorizált Európai Unióban 
napjainkban a közösségi közlekedést használók aránya 17 százalékos, míg Magyarországon ez az arány még meghaladja a 30\%-os értéket [1].

A közösségi közlekedés versenyképességének megtartása érdekében a lakosságot a szolgáltatás színvonalának növelésével, de az utas által megfizethető áron kell ezen eszközök használatának irányába csábítani úgy, hogy mindez még a szolgáltatók és az ellátásért felelősök részéről finanszírozható maradjon. Egy jól működő városi közösségi közlekedés a lakosságnak tisztább, élhetőbb lakhelyet, a vállalkozásoknak biztosabb beszállítói, munkavállalói piacot, míg a politikának egyfajta demonstrációs eszközt biztosít.

\section{A közösségi közlekedés intézményrendszere}

A közösségi közlekedés intézményrendszere hazánkban két pólusúnak nevezhető, országos és helyi szintű. Az országos és a helyi közösségi közlekedés, mint közszolgáltatási feladat ellátásáért felelősök kötelezettségeiket a vonatkozó 1370/2007/EK európai parlamenti és tanácsi rendelet - a vasúti és közúti személyszállítási közszolgáltatásokról szóló rendelet - rendelkezései, valamint a 2012. évi XLI. törvény a személyszállítási szolgáltatásokról törvényben foglaltak alapján látják el. Az európai parlamenti rendeletben és a személyszállítási törvényben foglaltak alapján, Magyarországon a helyi közösségi közlekedés ellátásáért, - így annak finanszírozásáért is - az adott település önkormányzata a felelős. Az ellátásért felelősök a közszolgáltatási feladatot a belső vagy külső szolgáltatókkal megkötött közszolgáltatási szerződések keretében látják el. A szolgáltató kiválasztásának, valamint a közszolgáltatási szerződés odaítélésének módját az 1370/2007/EK rendelet 5. cikke szabályozza. A közszolgáltatási szerződésekben külön rendelkeznek a szolgáltatókkal szemben támasztott minőségi követelményekről, elvárásokról.

\section{A szolgáltatás finanszírozása}

A közszolgáltatási feladat múködtetésére és finanszírozására nem csak az európai országok városait vizsgálva, de hazánkban a városok között is különböző megoldások, eltérő módszerek léteznek. A megrendelői, szolgáltatói szerepek, különböző operátorok bevonásának lehetősége és alkalmazása is eltérő megoldásokat mutat, azonban a szolgáltatás finanszírozása minden esetben az ellátásért felelős kötelezettsége. Ahhoz, hogy megismerhessük a hazai közösségi közlekedés finanszírozásában rejlő problémákat, szükséges a közlekedési szolgáltatók ráfordításainak és bevételeinek szerkezetét megvizsgálni.

\subsection{A szolgáltatás során felmerülő ráfordítások}

A közszolgáltatás biztosítása a közlekedési infrastruktúra, a pálya-, a felsővezeték hálózat kialakítása, a járműállomány beszerzése jelentős kezdeti beruházásokat igényel. A megvalósítás után ezen infrastruktúra múködtetése, fenntartása, karbantartása szintén nagymértékű ráfordításokat igényel.

Jelentős költségtényező az üzemanyag, a villamos energia költsége, az infrastruktúra üzemeltetésének műszaki, fenntartási anyagköltsége, valamint a karbantartás, javítás költsége, amely nagymértékben 
függ a megvalósított fejlesztések mértékétől, így a szolgáltatás és a járműpark műszaki színvonalától is.

Megállapítható, hogy az anyagjellegű ráfordítások aránya magasabb, eléri a 40-50 százalékos értéket is azon szolgáltatóknál, ahol a jármúállomány, vagy annak jelentős részének beszerzése nem támogatásból valósult meg. Ezen helyeken a járművek bérleti díja jelentős költség tényező, amely akár az üzemi szintű költségek 25 százalékát is meghaladhatja. Az is megfigyelhető, hogy a szolgáltatói tevékenységek velejárójaként, a hozzáadott emberi munka mértéke miatt a személyi jellegű ráfordítások aránya magas, legtöbb esetben eléri az üzemi szintű ráfordítások több, mint 30 százalékát, de néhány város esetében meghaladja a 40 százalékos mértéket is. Ahol nagyobb beruházás történt az elmúlt időszakban, ott jelentős mértékben megnövekedett az értékcsökkenési leírás is, melynek aránya meghaladhatja akár a 30 százalékot is [2]. Összességében megállapítható, hogy a szolgáltatás elvárt színvonalon történő ellátása érdekében a szolgáltatóknak jelentős költségvetéssel szükséges működniük, melynek fedezetét az utasoktól származó menetdíjbevételek mellett az ellátásért felelős, megrendelői oldalnak is finanszíroznia szükséges.

\subsection{A szolgáltatás bevételei az utasoktól}

Az utasok, mint a közösségi közlekedési szolgáltatás felhasználói, egyúttal annak meghatározó finanszírozói is. Hazánkban a helyi közösségi közlekedés bevételeinek mintegy 50-60 százaléka származik az utasok által megfizetett menetdíjakból. Az elszállított utasok száma a vidéki nagyvárosokban az elmúlt években stagnált. A menetdíjbevétel mértékére az értékesítési volumen alakulása mellett a menetdíjak árszínvonalának módosulása is hatással van. A tarifa alakulását többféle érdek befolyásolja. Egyik oldalról a politikai megfontolás, hiszen a viteldíj mértéke, a kedvezményrendszer kialakítása közhangulatot befolyásoló tényező. Másrészről befolyásolja az a haszonáldozat, melynek szintjén a lakosság számára még megéri a közösségi közlekedési eszközök választása, más alternatív közlekedési módok használatával szemben.

A tarifa mértékének meghatározása, azok módosítása hazánkban az ellátásért felelős hatásköre. Az elmúlt évek tapasztalatai alapján kijelenthető, hogy egy jelentősebb mértékű díjszabás módosítás az utas számot is nagymértékben befolyásolhatja. A közlekedési szolgáltatók nagy hangsúlyt fektetnek a menetjegy és bérlet ellenőrzési tevékenységre is. A jegyellenőrzési tevékenység a bevételi oldal mellett alapvetően befolyásolja az utasok szabálykövető magatartását is. Egy nem megfelelő hatékonyságú ellenőrzési rendszer nagymértékben kihatással van az értékszelvény értékesítésre is.

A menetdíj bevételek alakulását a hazánkban tapasztalható demográfiai változások is jelentős mértékben befolyásolják. Az elmúlt 15 évben jelentős változások figyelhetők meg Magyarország népességének számában, összetételében. Hazánk népessége jelentős mértékben csökkent ezen időszak alatt, de a lakosság korszerinti összetételében is változások mentek végbe. A 65 év felettiek száma jelentős mértékben növekedett, így ebből eredően az ingyenes utazásra jogosultak száma megnőtt. A 7 és 64 életév közötti lakosság száma mintegy 500 ezer fővel lett kevesebb, amely a fizető utasok számában jelentős csökkenést eredményez [3]. A más európai országokban történő munkavállalás eredményeként, több százezer magyar állampolgár él határainkon kívül, amely szintén az utasok számának csökkenését eredményezi. 


\subsection{A szolgáltatáshoz kapcsolódó kedvezményrendszer}

A helyi személyszállítási közszolgáltatási tevékenység kapcsán a kedvezményes (tanuló és nyugdíjas) bérletek után különböző mértékű támogatás vehető igénybe, a szociálpolitikai menetdíj-támogatás megállapításának és igénybevételének szabályairól szóló 121/2012. (VI.26.) kormányrendeletben meghatározottak alapján. A támogatás mértéke függ a közlekedési eszközök jellegétől akként, hogy autóbusz, trolibusz, vagy villamos járművekkel, illetve ezek kombinációjával lehetséges-e az adott településen közösségi közlekedési eszközt igénybe venni. A támogatást a szolgáltatók, közlekedésszervezők havonta tudják igényelni az adott hónapot követő hónap 20. napjától az állami adóhatóságtól az értékesített kedvezményes árú bérletszelvények darabszámának függvényében. Ezen - régebbi nevén fogyasztói árkiegészítésnek minősülő - támogatás összege 2006 óta változatlan mértékű, így ezen összegek valorizációja napjainkban már elengedhetetlen [4]. A jelenlegi bérletárakhoz képest a kiegészítés összege a legtöbb szolgáltató esetében már nem éri el a teljes árú értékszelvény árát, mely éves szinten több száz millió forintos bevétel-kiesést is jelenthet a szolgáltatóknak [5]. A támogatás mértékére további negatív hatást gyakorol a nyugdíjkorhatár folyamatos időbeli kitolódása is, amely miatt a nyugdíjas bérletszelvények értékesítésének visszaesése és az ehhez tartozó támogatás csökkenése figyelhető meg.

A helyi közösségi közlekedésben több kategóriába sorolva különböző jogosultságok alapján részesülhetnek az utasok 100 százalékos utazási kedvezményben a 85/2007. (IV.25.) Kormányrendeletben meghatározottak szerint. Többek között ingyenesen használhatják a közlekedési eszközöket életkor alapján kísérővel a 6 éves kor alattiak, valamint a 65 évnél idősebbek, valamint a fogyatékkal élők [6]. A rendeletben meghatározásra került az adott város lakosainak számára vetített támogatás mértéke, mely - hasonlóan a kedvezményes utazás után járó támogatáshoz - szintén több, mint egy évtizede nem került felülvizsgálatra, így az nem teljes mértékben és a valóságnak már nem megfelelő arányban fedezi az ingyenes utazások költségét a szolgáltatók felé. Meg kell jegyezni, hogy az ingyenes utazást ténylegesen igénybevevők számának egzakt mérése és az abból eredő finanszírozási hiány megállapítása nehéz feladat, de az ezen utazások mögötti állami támogatási rendszerből adódó bevétel-kiesés számítások szerint éves szinten több milliárdos nagyságrendű a szolgáltatóknál.

\subsection{Támogatási struktúra}

A helyi közforgalmú közlekedéssel rendelkező önkormányzatok különböző feltételek mellett igényelhetnek állami normatív támogatást is. A közösségi közlekedésre fordítható állami támogatások mértéke az állam költségvetésében kerül meghatározásra. A támogatás elosztása a települések között - az egyes közlekedési üzemágazatok tárgyévet megelőző évi üzemi szintű fajlagos ráfordításainak figyelembe vétele mellett - a kibocsátott személyszállítási teljesítmény (férőhely-kilométer), valamint a városi közlekedésben résztvevő járművek környezetvédelmi besorolása alapján képzett súlyszámok figyelembevételével történik. A támogatás odaítélését $\mathrm{az}$ is befolyásolja, hogy a települési önkormányzat a helyi közösségi közlekedés ellátásához, illetve fejlesztéséhez a tárgyévet megelőző évben, a tárgyévet megelőző évet érintően szolgáltatónként milyen összegű saját forrás átadásával 
járult hozzá [7]. A településeknek előirányzott támogatás az elmúlt években és 2019. évre is összesen 2050 millió Ft/év, mely összegből mintegy 80 közszolgáltatást ellátó önkormányzat igényel támogatást évente. Budapest esetében ezen előirányzat 12 milliárd Ft 2019-ben. A vidéki városok helyi közösségi közlekedésére jutó támogatás és a fővárosi előirányzat aránytalanságán túlmenően érdemes elemezni a további közösségi közlekedési módokra nyújtott támogatásokat. A 2019. évi költségvetésben a vasúti pályahálózat működtetésére 98113 millió $\mathrm{Ft}$, a vasúti személyszállítási közszolgáltatásra 168372 millió $\mathrm{Ft}$, a vasúti személyszállítás korábbi költségtérítéseinek elszámolására 4747 millió Ft költségtérítés szerepel. $\mathrm{Az}$ autóbusszal végzett, helyközi személyszállítási közszolgáltatások előirányzata 65300 millió Ft, míg az elővárosi közösségi közlekedésé 12997 millió Ft [8]. A jelentős eltérés egyik lehetséges oka az, hogy amíg a vasúti és helyközi közlekedés ellátása állami, addig a helyi közlekedés biztosítása önkormányzati feladat, annak ellátását a város költségvetésének terhére szükséges elszámolni, illetve ellentételezni a szolgáltatók felé.

A helyi közlekedésben tapasztalható, állami szerepvállalás hiányosságából származó aránytalanság jelentős terhet ró az önkormányzatok gazdálkodására, a feladat ellátásához még szükséges, további támogatások forrásának megteremtése évről-évre egyre nehezebb helyzetbe sodorja a városokat. A személyszállítási szolgáltatásokról szóló 2012. évi törvény 30 §-ában rögzítettek alapján „a közlekedési szolgáltató a közszolgáltatási tevékenységgel összefüggő, bevételekkel nem fedezett, a közszolgáltatási kötelezettség miatt felmerült indokolt költségeinek, valamint a szokásos mértékű, ésszerű nyereség megtérítésére jogosult" [9]. Az ellátásért felelős és a szolgáltatók között megkötött közszolgáltatási szerződésekben kötelező meghatározni - a szolgáltatók adatszolgáltatási kötelezettsége mellett - az ellentételezés megállapításának módját, számításának szabályait, metódusát, valamint a kompenzáció pénzügyi teljesítésének ütemezését.

\subsection{Bevételek és támogatások aránya}

A bevételek összetételét vizsgálva megállapítható, hogy a magyarországi városok esetében az utasok által megfizetett menetdíj mellett a szolgáltatás fenntartása érdekében egyéb bevételekre, különböző támogatásokra is szükség van.

Az összehasonlításból jól látható, hogy meglehetősen nagy szórást mutat a menetdíj bevételek és a támogatások aránya városonként (1. ábra). Az állam költségvetéséből a helyi közösségi közlekedésre biztosított támogatásának alacsony mértéke miatt az önkormányzatokra, mint ellátásért felelősökre hárul a finanszírozás jelentős része, melyet az ellentételezés megfizetésével tud a szolgáltatók felé rendezni. Hazánkban a helyi közösségi közlekedési ágazat finanszírozási helyzete napjainkra elérte azt a szintet, hogy annak megnyugtató és hosszútávon történő rendezése elengedhetetlenné vált a szolgáltatási színvonal, ezzel együtt a városi mobilitás fenntartása érdekében. 


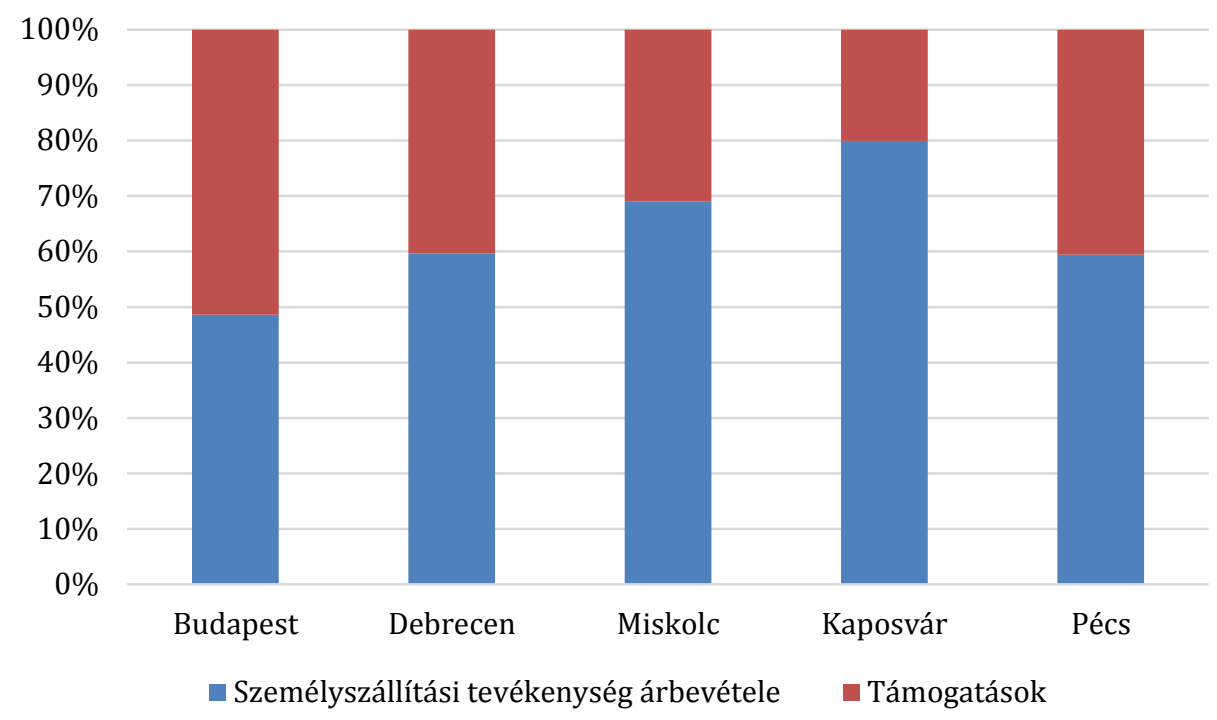

1. ábra: Magyarországi szolgáltatók utasbevételeinek és támogatásainak összevetése [10]

Napjainkban, az állam által megrendelt szolgáltatások esetében a bevételekkel nem fedezett indokolt költségeknek a megfizetése a szolgáltatók számára, az országos, regionális és elővárosi szolgáltatásoknál miniszteri rendelet formájában működik (MÁV, GYESEV, Közlekedési Központok). A helyi személyszállítási közszolgáltatási alapellátások esetében, ez azonban nem mondható el. Az önkormányzatok, mint a helyi közösségi közlekedési szolgáltatás megrendelői a saját költségvetési teherbíró képességeikhez igazítják a szolgáltatás bevételekkel nem fedezett költségeinek kompenzálását, így a szolgáltatók folyamatosan alulfinanszírozottak, likviditási problémákkal küzdenek.

\section{Összegzés}

Az utasok által megfizetett menetdíj bevételek mellett a rendszer finanszírozásához jelentős állami forrás is szükséges, amely a normatív támogatási rendszer átdolgozásával az állami szerepvállalás növelésével valósítható meg. A hazai szolgáltatók bevételeinek vizsgálatakor egyértelműen megállapítható az, hogy a jelenleg érvényben lévő kedvezményrendszer miatt jelentős hiány keletkezik a finanszírozási rendszerben. A kedvezményes bérletszelvények és az ingyenes utazások után megállapított szociálpolitikai menetdíj-támogatás mértékének felülvizsgálata indokolt és időszerű. A kedvezményes bérletek után járó árkiegészítés növelésével és az ingyenes utazások után megállapított térítés mértékének a ténylegesen megvalósuló ingyenes utazások számához történő igazításával a finanszírozási hiány jelentős mértékben csökkenthető. A Magyar Államkincstár által nyújtott szociálpolitikai kedvezmények rendszere is igényli az átstrukturálást, hiszen jelenleg ezen kedvezmények biztosítására a szolgáltatók egyáltalán nem kapnak ellentételezést. Az elektronikus jegy és bérletrendszer országos szintű mielőbbi bevezetése segítséget jelenthet az ingyenes utazások pontos mérhetősége és a szolgáltatókkal történő korrekt és teljes körű elszámolás érdekében. 
International Journal of Engineering and Management Sciences (IJEMS) Vol. 4. (2019). No. 3

\section{Hivatkozások}

[1] Eurostat (2017) Passenger Transport Statistics. Modal split of inland passenger transport

[2] Közlekedési szolgáltatók éves számviteli törvény szerinti beszámolói

[3] KSH Központi Statisztikai Hivatal (2017) Népesség, népmozgalom

[4] 121/2012. (VI.26.) kormányrendelet

[5] Közlekedési szolgáltatók díjszabásai

[6] 85/2007. (IV.25.) Kormányrendelet

[7] Hivatalos Értesítő 39. szám (2018) A települési önkormányzatok helyi közösségi közlekedésének támogatásáról szóló pályázati kiírás

[8] 2018. évi C. törvény Magyarország 2019. évi központi költségvetéséről

[9] 2012. évi XLI. törvény a személyszállítási szolgáltatásokról

[10] Közlekedésszervezők és szolgáltatók kiegészítő mellékletei 2016. év 